Available online at: https://proceeding.researchsynergypress.com/index.php/rsfconferenceseries1

RSF Conference Series: Business, Management and Social Sciences

e-ISSN 2807-5803/p-ISSN 2807-6699

Volume 1Number 5 (2021): 74-83

\title{
Risk Management of Mice Tourism in XYZ Firm During the Covid-19 Pandemic
}

\author{
Jason Tan', Aldi Ardilo² \\ ${ }^{1}$ Center for Risk Management and Sustainability, Indonesia \\ ${ }^{2}$ CyberWhale, Indonesia
}

\begin{abstract}
This paper explores the implementation of risk management maturity of MICE tourism-sector organisations in XYZ firm which located in Indonesia, precisely in Bandung City, which has a population of 2.510 .103 people. The research used a qualitative-descriptive design in the form of a case study at XYZ firm. This study uses primary data and secondary data as supplementary. Primary data was collected by conducting semi-structured interviews with subjects whose roles and functions are relevant to facilitating XYZ firm's strategic initiatives and programs. The findings indicate that XYZ firm was at the initial level in implementing risk management which positively corresponds with its resilience and sustainability - XYZ had a difficult time bouncing back, surviving, and thriving this global pandemic. The results of this research may assist decision-makers on the importance and the dynamics of risk management implementation, particularly for the MICE tourism industry in Indonesia.
\end{abstract}

Keywords: Risk Management Maturity, Sustainability, Tourism

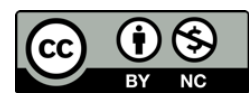

This is an open access article under the CC-BY-NC license.

\section{INTRODUCTION}

The coronavirus outbreak brings a high degree of increasing risk and uncertainty in achieving the defined goals for many enterprises, including those in the tourism industry (WTO, 2020). The COVID-19 pandemic has had a significant impact on social life as well. The very rapid spread required the government to implement social restrictions. This policy feels uneasy because humans, as social beings, must be limited in terms of their space of movement. This phenomenon indicates that social restriction is somewhat a sacrifice even though it is due to coercion. The sacrifice may look simply, but in reality, it is much more complex because the missing social interactions are more than just friendly talk, work, or travel with other people, but social interaction also involves the people around the interaction, both with economic factors or not. Tourism is one of the sectors worst affected by the COVID-19 pandemic-and (Ritcher, 2020) quoted from the World Economic Forum estimated that global industrial sector losses due to the COVID19 pandemic would reach more than $\$ 1$ trillion, with more than 120 million workers are at risk of becoming unemployed. In addition, McKinsey's research results also support the above data by projecting those small businesses of accommodation and food service in the United States will fully recover early 2024 - 2025 (Dua \& Mahajan, 2020).

The World Tourism Organization (UNWTO) suggests that people who travel for business and other professional reasons are also considered tourists. Over the years, people have realised the importance of developing this particular area of tourism from which it caters for higher quality, higher costs, and, therefore, a higher yield end of the market (Trišić \& Arsenov-Bojović, 2018). This more remarkable power of business tourists means increased economic benefits for the host and more outstanding local taxes and retributions. Thus, the importance of the MICE tourism industry. MICE stand for Meetings, Incentives, Conferences or Congresses or Conventions, and Exhibitions-or, people very often called it by the term of business travel.

Likewise, in any other country, in Indonesia, the absence or lack of travel activities has made the people's economy, whose sources of income depend on the tourism sector, very uncertain and drastically reduced.

Corresponding author

nc.jasontan3@gmail.com; aardiloalijoyo@cyberwhale.co.id

DOI: https://doi.org/10.31098/bmss.v1i5.454

Research Synergy Foundation 
Jason Tan, Aldi Ardilo

For example, (Yanwardhana, 2021) on CNBC Indonesia explained that Bali-Nusa Tenggara has the worst economic growth in Q1-2021 at minus 5.15\% compared to Java 0.83\%, Sumatra minus 0,86\%, and Sulawesi Maluku Papua 3,26\%. The data shows that the economy has not yet risen in the tourism area, directly threatening the community's economy. Whereas in regards to the MICE industry, by the end of 2020, it had sustained at least IDR 44.3 trillion (US\$ 3.1 billion) in losses as a result of the COVID-19 pandemic (The Jakarta Post, 2020). In order to contain the spread of COVID-19, the Tourism and Creative Economy Ministry conventions gave suspensions for MICE events, particularly for conventions and exhibitions. In other words, the MICE tourism industry is among the sectors hardest hit by the pandemic.

The MICE tourism industry does not mean that it cannot operate and has no solution to stay alive. Companies can be more creative and adaptive to prevailing conditions and regulations. This study also takes the example of the MICE tourism industry in Vietnam from (Gia Hoang et al., 2021), which has proven to survive by implementing several strategies. A hotel called Viehost responsively makes a strategy as a paid hotel quarantine service. Together with the government and other stakeholders, Viehost works closely together so that it was appointed to be one of the first hotels to become a paid hotel quarantine service. This strategy focuses on profitability and job security but provides full service. The cleanliness of the Viehost hotel has been tested by doctors and experts from the Vietnamese Ministry of health by implementing very strict health protocols for hotel workers and guests. Viehost also provides food services that are guaranteed to be clean and according to the standards of the Ministry of health. Every day the doctor will visit quarantine guests so that the guest's condition can be well controlled. In addition, Viehost also cuts costs by reducing the use of electricity and elevators. Reduction of employees also had to be done in order to keep the company afloat. In addition to cutting costs, Viehost conducts market development to countries with low COVID-19 cases, such as New Zealand and Korea. Loyal consumers also receive promotional emails for paid quarantine services and regular hotel services according to government standards. Viehost's strategy has had a positive impact, marked by a significant and consistent increase in revenue after experiencing losses in the first two months of COVID-19 cases in Vietnam. The addition of the number of employees is also carried out gradually with increasing income. Viehost's response to the COVID-19 pandemic has indirectly illustrated the application of risk management. However, with a reactive response and seeing positive results, risk management positively influences the company's sustainability.

For many enterprises, including organisations in the MICE tourism industry, a rudimentary area of interest is the organisation's sustainability and efficiency of operations. Among these issues, risk management is one of the most imperative variables that an organisation should pay attention to (Bera et al., 2020). By identifying the various kinds of threats and opportunities, which could either inhibit or enhance organisation's operating efficiency and sustainable growth, management could install controls over those factors and attenuated the impacts to objective achievability. In addition, the risk is in itself probably one of the fastest-growing business fields (Grote, 2011) - and it has become an influential agenda, for over a decade, in a wide array of sectors and industries across the globe (Renn, 1998).

Basically, every organisation has done risk management activities, whether intentionally or not (CRMS, 2019). The application of risk management provides an opportunity for tourism sector practitioners to see the bigger picture of this pandemic by implementing risk management. The organisation can analyse the worst to the best and carry out strategic planning based on these analyses so that when a pandemic occurs, the organisation can immediately make strategic adjustments according to the conditions at that time. The expected result of implementing risk management is the organisation's sustainability on both financial and non-financial aspects to survive and compete. Moreover, according to a publication by AON risk maturity index, Chris Ittner with The Wharton School determined a statistically significant relationship between the organisation's risk maturity rating and financial performance (PR Newswire, 2011) - more specifically they explain that the findings reflect that higher risk maturity ratings are associated with improved return on assets and stock performance. Thus, the aim of this study is to explore 
Jason Tan, Aldi Ardilo

the maturity of an organisation in MICE tourism in implementing risk management, especially during the COVID-19 pandemic.

\section{LITERATURE REVIEW \\ Mice}

According to (Kementerian Pariwisata Republik Indonesia, 2017), MICE is business tourism. MICE stands for Meetings, Incentives, conventions, and exhibitions are the provision of services for a meeting of a group of people, travel organizers for employees and business partners in return for their achievements, as well as holding exhibitions in the context of disseminating information and promoting goods and services on a national, regional and international scale.

MICE has a huge contribution to a country in terms of financial and non-financial. In the financial sector, according to (Smagina, 2017) in addition to adding jobs, MICE can also increase investment, development or improvement of infrastructure, accommodation, and venues that can be enjoyed by visitors and, most importantly, the local community. In the end, the regional economy will also improve on the non-financial side. (Murdopo, 2011) stated that MICE could give pride and strengthen the nation's diplomacy. In addition, the direct effect that can be felt is an increase in the image and promotion of the nation's culture. Murdopo added that MICE from a tourism perspective could contribute by bringing in large numbers of tourists, staying longer, and involving the amount of money spent.

Meanwhile (Marques \& Santos, 2016) argues that MICE can provide two significant benefits, namely the main benefit and the territorial benefit. First, the main benefits that can be felt are reducing seasonality in hotel occupancy and related services such as catering and entertainment. Second, increasing investment and creating jobs in the tourism sector. Third, increase the average visitor spending. Fourth, it can reduce the environmental impact because tourism activities are carried out in large numbers to increase the use of public transportation. Fifth, increase the growth of products that have great potential. The benefits of the territory that can be felt are that the region's diversity encourages the creation and growth of various products.

However (Sumithra \& Mohan Mishra, 2016) identified several factors that can increase the impact of MICE tourism on the local economy, including building the required skills and their application, supply chain management, research and collaboration, and infrastructure.

\section{Risk Management Based on ISO 31000}

Risk management is a process that aims to help organisations understand, evaluate and take action on all their risks to increase the probability of success and reduce the likelihood of failure, according to (Hopkin, 2019). Risk-based on SNI ISO 31000:2018 defined as "the effect of uncertainty of a goal." Risk happens when an organisation or person sets a goal, so an unexpected event can always happen. That possibilities occur because there is a lack of information to achieve the goal, which can be defined as uncertain. The uncertain condition causes some effects. Effects can be defined as deviation from the expectation result, whether it is better or worse. In short, the managing risk might have a positive or negative effect that will affect the goal.

Alijoyo (2021) said Enterprise risk management (ERM) is the leading approach to managing and optimising risks, enabling a company to determine how much uncertainty and risk are acceptable to an organisation. Successful companies need a complete understanding of ERM that analyses what risks to avoid and what to exploit. Companies must view risk as a potential opportunity while also understanding there are possible undesirable outcomes. Companies' future success will depend on the ability to weigh the expected risks versus rewards on an ongoing basis. While (Polinkevych et al., 2021) state understanding the nature and types of business risks, setting up the process of identifying risks and managing risks help managers make more conscious and well-informed decisions. Organisations that 
Jason Tan, Aldi Ardilo

know risk management can improve organisational performance by positively influencing organisations' innovativeness, agility, success, sustainability, and growth. (Durst et al., 2019).

Risk management is a tool that helps an organisation achieve its goals. In order to achieve company goals, a principle called SMART (Specific, Measurable, Attainable, Relevant, Time-Bound) is also needed. SMART principles are used to formulate the most appropriate goals for the company and evaluate how to achieve these goals. Measurable, one of the principal components, is essential because success in achieving goals requires clear indicators.

On the other hand, success indicators can also be used to measure the impact of risk management implementation, whether the better or more mature the implementation of risk management will positively impact the organisation.

\section{Risk Maturity}

Risk maturity models help understand the degree of sophistication of risk management practices and their effectiveness at each stage (Wieczorek-Kosmala, 2014). Meanwhile (Hoseini et al., 2019) stated that risk maturity is an effective tool for companies to improve and monitor risk management practices. An organisation's risk maturity can be assessed with several levels. Ciociari and Blattner stated the level of risk maturity contain (i) very weak, (ii) poor, (iii) mid, (iv) good, and (v) optimised (Wibowo \& Taufik, 2017). (Proença et al., 2021) said the risk management maturity levels start from level 0 - Non Existent RM, level 1 - Initial RM, level 2 - Managed RM, level 3 - defined RM, level 4 - Quantitatively Managed RM, level 5 - Optimising RM. Meanwhile, ERMA RM3 states five levels of risk maturity starting from Initial, Repeatable, Defined, Managed, and Optimised. The model also identifies six attributes of risk management maturity: a risk management framework, risk management process, process management, performance management, risk management culture, and resilience and sustainability.

Table 1. Risk Management Maturity Level (ERMA RM³, 2020)

\begin{tabular}{|c|l|}
\hline MATURITY CRITERIA & \multicolumn{1}{c|}{ INTERPRETATION } \\
\hline $\begin{array}{c}\text { INITIAL } \\
(\mathbf{0 - 2 0 \% )}\end{array}$ & $\begin{array}{l}\text { Risk management is still ad-hoc, relies on individual initiative. It is also or } \\
\text { limited to a particular risk aspect and used to manage only certain risk, and } \\
\text { relief on corrective actions. }\end{array}$ \\
\hline $\begin{array}{c}\text { REPEATABLE } \\
\text { (21-40\%) }\end{array}$ & $\begin{array}{l}\text { Risk management starts systematically implemented. However, it is not } \\
\text { integrated with organisational governance and organisational management. } \\
\text { Competency, leadership, and commitment to risk management are not evenly } \\
\text { distributed. }\end{array}$ \\
\hline $\begin{array}{l}\text { DEFINED } \\
\mathbf{( 4 1 - 6 0 \% )}\end{array}$ & $\begin{array}{l}\text { Risk management has been implemented systematically and consistently } \\
\text { practiced as per ISO 31000 Risk Management Guideline or Standard. It has } \\
\text { begun to be integrated with organizational governance and most of the } \\
\text { organisational management. Competency, leadership, and commitment to } \\
\text { risk management have been evenly distributed. However, positive behaviour } \\
\text { in managing risk remains limited. }\end{array}$ \\
\hline $\begin{array}{l}\text { MANAGED } \\
\text { (61-80\%) }\end{array}$ & $\begin{array}{l}\text { Risk management has been integrated with organisational governance and } \\
\text { organizational management systematically and consistently practiced as per } \\
\text { ISO 31000 Risk Management Guideline or Standard. It becomes a culture that } \\
\text { includes the strong support of competency, leadership, and commitment to } \\
\text { risk management. Positive behaviour in managing risk is prevalent }\end{array}$ \\
\hline
\end{tabular}




\begin{tabular}{|c|c|}
\hline & $\begin{array}{l}\text { throughout the organisation and consistently supported with reviews, } \\
\text { corrective actions, and improvements as needed. }\end{array}$ \\
\hline $\begin{array}{l}\text { OPTIMISED } \\
(81-100 \%)\end{array}$ & $\begin{array}{l}\text { Risk management is an integral part of organisational governance and } \\
\text { organizational management, systematically and consistently practiced as per } \\
\text { ISO } 31000 \text { Risk Management Guideline or Standard. It has been internalised } \\
\text { and rooted as an organizational culture with strong competency, leadership, } \\
\text { and commitment to risk management. Positive behaviour in managing risk } \\
\text { has been manifested throughout and at all levels of the organisation, } \\
\text { supported with reviews, corrective actions, and improvement as needed. It } \\
\text { becomes the strong pillar of business resiliency and sustainability }\end{array}$ \\
\hline
\end{tabular}

\section{RESEARCH METHOD}

\section{Research Approach}

This research is a case study using applied research methods. The data collected is qualitative data, which means that the data is in words and is taken from a set of structured questions (Sekaran \& Bougie, 2016) and analysed descriptively.

\section{Methodology}

The proxy used to indicate an organisation's risk management implementation is risk management maturity. Semi-structured interview sessions were held with six respondents whose roles and functions are relevant to facilitating strategic initiatives and programs in XYZ firm. The interview questions will be constructed based on ERMA RM ${ }^{3}$ that uses both primary and secondary data gathering. The authors will observe the dynamics of risk management implementation according to ISO 31000 in XYZ firm.

\section{Validity and Reliability}

The validity and reliability of this study used the triangulation method. Primary data collection uses semistructured interviews and is supplemented by secondary data from companies. Both types of data are also used to confirm each other's statements.

\section{FINDINGS AND DISCUSSION}

\section{Organisational Context}

XYZ firm has been in the MICE tourism industry for more than ten decades, providing a golf course and a resort since it was established in 1917; it is the oldest golf course in Indonesia, and even the locals see the entity as a heritage to Bandung city. The top management classified the whole management into two big business units: golf course and resort divisions. At the moment, XYZ firm has around more than 300 employees, and around 30 of them are dedicated to running the resort. In addition, although it serves both national and international guests, the golf course is particularly notorious for locals since it is the only golf course in West Java located in the city centre and can be reached within $8 \mathrm{~km}$ from the Bandung City Hall.

\section{RESULT}

Several key people in the managerial positions of XYZ firm were semi-interviewed about their takes on risk management implementation based on ISO 31000:2018 and the ERMA RM3. The authors measured, gathered, and collected data on this particular maturity assessment method through document analysis, interviews or testimonials with top management and some representatives of XYZ's leaders and/or critical people. Furthermore, since there are no formal risk management divisions, surveys regarding risk management were also distributed to some key people to supplement all of the data as mentioned above collection methods to gain more insights and accurate assessment. Table 2 indicates the maturity level of $\mathrm{XYZ}$ firm in terms of risk management implementation based on the realisation of each attribute throughout the existing risk management process. 
Table 2. XYZ Firm's Risk Management Maturity Level

\begin{tabular}{|c|c|c|c|}
\hline ATTRIBUTES & SCORE [0-5] & AGGREG & TURITY \\
\hline Risk culture & 0.67 & \multirow{6}{*}{$\begin{array}{c}0.99 \\
{[19.86 \%]}\end{array}$} & \multirow{6}{*}{ INITIAL } \\
\hline Risk management framework & 0.29 & & \\
\hline Risk management process & 0.75 & & \\
\hline Management process & 1.75 & & \\
\hline Performance management & 1.00 & & \\
\hline Resilience and sustainability & 1.50 & & \\
\hline
\end{tabular}

Table 2 indicates that XYZ firm is at an initial stage of risk management maturity. According to ERMA RM3, $\mathrm{XYZ}$ firm implemented and conducted risk management haphazardly and, in an ad,-hoc manner as it highly relied on the individual initiative-not viewed as organizational or strategic issues. They tended to manage only a certain set of risks through a particular risk aspect. Moreover, XYZ firm had no formal structure, documents, policies, or risk management procedures, although it made some attempts to manage some of the identified risks. In terms of its management process, XYZ has started to implement it instead systematically regarding — even though it has not fully integrated-the performance management process.

On the other hand, the least score XYZ had was in the risk management framework-which barely existed-hence, a tiny amount of leadership and commitment towards risk management were shown. It explains the low level of risk culture in which risk management is still carried out in silos. For that reason, within XYZ firm, there is still no systematic risk management process that has been properly implemented. Therefore, although financial-wise, XYZ was surviving the pandemic, its risk management was separated from its performance management and its resilience and sustainability management.

\section{DISCUSSION}

According to one of the directors (informant A), in the industry, XYZ firm was not the best in Indonesia; however, it offers a warmth and a sense of community to the customers-even some of the regular customers have a high level of belongingness, and they perceive a sense of kinship as well. Some consider $\mathrm{XYZ}$ as "home" where they could freely express their expressions and have fun with their friends, colleagues, and business partners; they would feel "away" when they come and play in another golf course. The head of resort (informant B) added, due to the high level of community sense, everything was being conducted in a relatively informal manner-without any rigid procedures and policies. Even if some policies are established, there were neither enforced, implemented, nor well-executed-it will remain a mere formalisation.

When the spread of coronavirus entered Indonesia, Jakarta, as the capitol, was the one most affected; nevertheless, in the middle of the first quarter of 2020, the West Java province, including Bandung city, 
Jason Tan, Aldi Ardilo

was also the one most affected began to receive the consequences of this pandemic. The operations head (informant C) emphasised that predominantly the impact of the COVID-19 pandemic was due to the uncertain and volatile regulatory environment, which essentially limit people's mobility and interaction with other human beings, in particular with those with whom you do not live-the social and/or physical distancing (the terms are used intermittently in Indonesia). The majority of events held in XYZ are meetings, conferences, and other business travel agendas that involve mainly physical human and social interactions.

The general manager (informant D) pointed out that compared to the first quarter of 2019, the gross profit in the first quarter of 2020 fell quite drastically by almost $50 \%$. Some of the informants agreed that it was mainly due to the impact of the COVID-19 pandemic. Nonetheless, the finance department (informant E) asserted that there were no aggressive campaigns or an intensive marketing effort to promote XYZ for a decade-the customers mostly were regulars, and the non-regulars mainly came with the regulars. Ultimately, they also became a regular customer. The way of their marketing corresponds with XYZ strategic management, in particular in managing organisational risks. From the interview sessions, the analysis indicates that since XYZ did not have any specific methodology and commitment to manage risk, it reactively implemented risk management and only applied corrective actions instead of what ISO 31000:2018 suggested- "risk should be managed proactively".

Risk management has three types of control, namely preventive, detective, and proactive. Since XYZ firm primarily managed their organisation's risk reactively-meaning, to react to a certain stimulus or an event that has or is occurring-it tends to manage only the impacts or consequences of the event, not the likelihood. For instance, during the beginning of the COVID-19 pandemic, The risk treatment they took was to "share the risk" of the whole resort management to a professional third-party (one of reactive risk management / corrective actions) - Share the results of company's performance to another party to minimise losses borne by the company. XYZ's risk-sharing decision considered quite right can carry out the company, especially in financial terms. The volatile conditions of COVID-19 and the fluctuating government regulation create a high level of uncertainty for the whole city, including people and companies. XYZ can easily lose in this situation, so that outsource the management to a professional third party is needed and have the advantage to share the company's financial result, moreover if the result is loss.

Since there were more people work from home, more local people have their meetings and MICE activities at XYZ, since it offers (coincidentally) a large open-air environment and space, and the sun is bathing all over the patio and balconies since the resort is some inches away from the tee-off (WHO also suggested humans do a sunbathe in order to improve immunity and keep the coronavirus away). This blessing must be used. Besides downside risk, there are upside risks that can be found and maximised by XYZ to survive the pandemic. With the advantage in hand, XYZ can exploit the opportunity to reach new customers, driving better financial results. Still ad-hoc and intuitively manage risks, though still survived. If they could better manage the risks, they could even thrive the pandemic or the emerging, new risks. XYZ does not need to worry about the risk because if it is appropriately managed, risk will maximise its potential and reach its purpose easier.

All in all, financial wise, they are doing okay, surviving this pandemic but not thriving. Considering the low-risk maturity they have, XYZ was lucky to survive this pandemic still and stay trying hard to survive because the uncertainty about this pandemic will stay remain. On the other hand, this financial condition shows us the righteousness of risk-sharing decisions, even though executed reactively at the right time and right party so XYZ can still survive. This financial condition shows us too that in this case, risk maturity does not affect sustainability significantly.

However, strategic management or risk management speaking, they are far from mature, still at the initial level. Some formalised procedures are recommended to be implemented and enacted. Lacking risk 
management leadership is the one element that could make it proactive instead of reactive risk management. Risk management that proactively executes can help achieve the company's goals with exemplary process implementation and help the company anticipate undesirable events. XYZ still needs to implement better and systematic risk management because learning from this pandemic, anything can happen suddenly. Especially when looking ahead, projected economic conditions will improve after the city reaches the immunity herd, but uncertainty will remain considering this virus evolves.

XYZ Needs a higher maturity level in implementing risk management to be resilient and achieve sustainable growth. Like those mentioned above, tough risk maturity does not affect sustainability significantly in this case, however, XYZ still needs to implement risk management proactively to compete and grow further with all of their advantages and value propositions. To do so, XYZ needs to involve and integrate more risk management into business strategies formulation and implementation more effectively.

\section{CONCLUSION}

Risk maturity in XYZ firm is categorized very low at the initial level, which is indicated by risk management used to manage only certain risks, relief on corrective action, and reactively implementation. However, the effect of risk maturity on sustainability is not significant as seen from the financial performance of XYZ which is still able to survive even though it is not in a good performance. However, this condition of financial performance can still be tolerated considering that it was difficult to achieve optimal performance in government regulation of social restriction. XYZ's sustainability may be in a safe condition, nevertheless, XYZ needs to increase the risk maturity considering the level of uncertainty still high and learn from the COVID-19 pandemic, uncertainty can come any time unexpectedly. 
Jason Tan, Aldi Ardilo

\section{REFERENCES}

Alijoyo, A. (2021). Enterprise Risk Management Using ISO 31000. PT Cipta Raya Mekar Sahitya.

Bera, A., Drela, K., Malkowska, A., \& Tokarz-Kocik, A. (2020). Mitigating Risk of the Tourism Sector in the European Union Member States During the COVID-19 Pandemic, European Research Studies Journal Volume XXIII Issue 4, 107-122

Center for Risk Management and Sustainability (CRMS) Indonesia. (2019). Sustaining through GRC. Governance Risk Management Compliance National Survey 2019, pp. 1.

Dua, A., \& Mahajan, D. (2020, Juli 7). US small-business recovery after the COVID-19 crisis. McKinsey. https://www.mckinsey.com/industries/public-and-social-sector/our-insights/us-smallbusiness-recovery-after-the-covid-19-crisis

Durst, S., Hinteregger, C., \& Zieba, M. (2019). The linkage between knowledge risk management and organizational performance. Journal of Business Research, 105, 1-10. https://doi.org/10.1016/j.jbusres.2019.08.002

ERMA. (2020). ERMA Risk Management Maturity Model ISO 31000 RM3. Methodology andApplication of ISO 31000-Based Risk Management Maturity Assessment, https://erm-academy.org.

Gia Hoang, T., Tuyet Truong, N., \& Minh Nguyen, T. (2021). The survival of hotels during the COVID-19 pandemic: a critical case study in Vietnam. Service Business, 15, 209-229. https://doi.org/10.1007/s11628-021-00441-0

Grote, Gudela. (2011), "Risk management from an organizational psychology perspective: A decision process for managing uncertainties", Die Unternehmung. 65. 10.5771/0042-059X-2011-1-69.

Hopkin, P. (2019). Fundamentals of Risk Management (Fourth). Kogan Page Limited. https://doi.org/10.14254/1800-5845/2021.17-3.1

Hoseini, E., Hertogh, M., \& Bosch-Rekveldt, M. (2019). Developing a generic risk maturity model (GRMM) for evaluating risk management in construction projects. Journal of Risk Research, 24(7), 889908. https://doi.org/10.1080/13669877.2019.1646309

ISO. (2018). "ISO 31000:2018 Risk Management Guidelines", International Organization for Standardization, Geneva, Switzerland.

Marques, J., \& Santos, N. (2016). Developing business tourism beyond major urban centres: The perspectives of local stakeholders. Tourism and Hospitality Management, 22(1), 1-15. https://doi.org/10.20867/thm.22.1.3

Murdopo. (2011). Potensi Industri MICE Indonesia. In Warta Ekspor (hal. 4-5). Kementerian Perdagangan Republik Indonesia. www.djpen.kemendag.go.id

Kementerian Pariwisata Republik Indonesia. (2017). Pedoman Destinasi Pariwisata Berkelanjutan, Pub. L. No. 14, 1.

Polinkevych, O., Khovrak, I., Trynchuk, V., Klapkiv, Y., \& Volynets, I. (2021). Business Risk Management in Times of Crises and Pandemics. Montenegrin Journal of Economics, 17(3), 99-110. https://doi.org/10.14254/1800-5845/2021.17-3.8

PR Newswire. (2011, Oktober 3). Link Confirmed Between Financial Performance and Risk Management Maturity: Aon and Wharton School: Early finding indicated by Aon Risk Maturity Index, Wharton School analysis - ProQuest. PR Newswire.

Proença, D., Estevens, J., Vieira, R., \& Borbinha, J. (2021). Risk Management A Maturity Model based on ISO 31000 .

Renn, O. (2008). "Risk Governance - Coping with uncertainty in a complex world", London.

Ritcher, F. (2020, September 2). COVID-19 Could Set The Global Tourism Back 20 Years. World Economic Forum. https://www.weforum.org/agenda/2020/09/pandemic-covid19-tourism-sectortourism/

Sekaran, U., \& Bougie, R. (2016). Research Methods for Business. In Wiley (Seventh ed). John Wiley \& Sons. https://doi.org/10.1088/1751-8113/44/8/085201

Smagina, N. (2017). The internationalization of the Meetings-, Incentives-,Conventions- and Exhibitions(MICE) industry: Its influences on the actors in the tourism business activity. Journal of Economics and Management, 27, 96-113. https://doi.org/10.22367/JEM.2017.27.06 
Jason Tan, Aldi Ardilo

Sumithra, D., \& Mohan Mishra, J. (2016). Efficacy of MICE Tourism Industry And Supply Chain Management as an Integrated Approach. International Journal of Management Research \& Review, 6(3), 2249-7196. www.ijmrr.com

The Jakarta Post. (2020, Desember 10). MICE industry sustains Rp 44.3 trillion in losses from COVID-19 pandemic - Business - The Jakarta Post. The Jakarta Post. https://www.thejakartapost.com/news/2020/12/10/mice-industry-sustains-rp-44-3-trillionin-losses-from-covid-19-pandemic.html

Trišić, I. \& Arsenov-Bojović, V.(2018). The Role of MICE Industry In Tourism Development. $3^{\text {rd }}$ International Scientific Conference: Tourism in function of development of the Republic of Serbia. University of Kragujevac.

Wibowo, A., \& Taufik, J. (2017). Developing a Self-assessment Model of Risk Management Maturity for Client Organizations of Public Construction Projects: Indonesian Context. Procedia Engineering, 171, 274-281. https://doi.org/10.1016/J.PROENG.2017.01.335

Wieczorek-Kosmala, M. (2014). Risk Management Practices From Risk Maturity Models Perspectives. Journal of East European Management Studies, 19(2), 133-159. https://doi.org/10.1688/JEEMS2014-02-Wieczorek-Kosmala

WTO. (2020). https://www.wto.org/english/tratop_e/covid19_e/covid19_e.htm

Yanwardhana, E. (2021). Dihantam Covid-19, Begini Kondisi Menyedihkan Ekonomi Bali. CNBC Indoneisa. https://www.cnbcindonesia.com/news/20210522173134-4-247581/dihantam-covid-19begini-kondisi-menyedihkan-ekonomi-bali 